\title{
Model Granuloma Tuberculosis In Vitro Sebagai Deteksi Awal Tingkat Keparahan Penderita Tuberkulosis
}

\author{
Imam Agus Faizal ${ }^{1}$, Agung Dwi Wahyu Widodo ${ }^{2}$, Jusak Nugraha ${ }^{3}$ \\ ${ }^{1}$ Jurusan Sarjana Terapan Teknologi Laboratorium Medis, STIKES Al-Irsyad Al-Islamiyyah Cilacap, Indonesia \\ ${ }^{2}$ Departemen Mikrobiologi Klinik, Fakultas Kedokteran, Universitas Airlangga Surabaya, Indonesia \\ ${ }^{3}$ Departemen Patologi Klinik, Fakultas Kedokteran, Universitas Airlangga Surabaya, Indonesia
}

Article Info
Article history:
Received Jul $06^{\text {th }}, 2020$
Revised Aug $28^{\text {th }}, 2020$
Accepted Sep $01^{\text {st }}, 2020$

\section{Keyword:}

Granuloma

Tuberkulosis

Mycobacterium Tuberculosis

\begin{abstract}
Mycobacterium tuberculosis (Mtb) is the cause of tuberculosis (TB) in humans, causing death and is an infectious agent in humans. TB remains one of the world's deadliest infectious diseases and is considered a major global health problem, with an estimated 8.6 million people suffering from TB, and 1.3 million dying. This type of research is a pure experiment with an in vitro method of making a TB granuloma model similar to humans. The aim of this study is to detect the severity of tuberculosis. The results showed that on day 1 the granuloma had not yet been formed because the granuloma structure had not yet been formed because the blood immune cells in PBMC media containing lymphocytes and monocytes had not yet responded to Mtb infection. On the second day, the granuloma structures surrounding the Mtb bacteria have started to form to form aggregations. Day 3, many other cell types also occupy the granuloma, such as neutrophils, dendritic cells, B and T cells, natural killer cells, fibroblasts and cells that secrete extracellular matrix components. On the 4th day the granuloma experiences granulation and the granuloma structure breaks and the maximum damaged aggregation occurs on the 5th day. When the host's immune system weakens, the granuloma will burst and the Mtb bacteria will infect and reactivate. The results of this study show that the severity of tuberculosis sufferers can be detected early by the in vitro granuloma observation method by looking at the morphology of tuberculosis granuloma formation so that in order to provide the right drug therapy, this research can even be used as an initial stage of vaccine perfection in Mycobacterium tuberculosis bacterial infection.
\end{abstract}

Copyright $(\mathrm{C}$ Jurnal Analis Medika Biosains (JAMBS) All rights reserved 


\section{Pendahuluan}

Bakteri Mycobacterium tuberculosis (Mtb) merupakan penyebab penyakit Tuberculosis (TB) pada manusia, menyebabkan kematian dan salah satu agen infeksius pada manusia di dunia (Fitzgerald et al., 2014). $\mathrm{Tb}$ adalah penyakit menular yang masih ada dan menjadi ancaman utama dalam hal mortalitas dan morbiditas, sedangkan hampir seperempat global populasi terinfeksi secara laten oleh Mtb (1,7 miliar individu), hanya 510\% dari orang yang terinfeksi berkembang menjadi tuberkulosis aktif (Mezouar et al., 2019). Mtb merupakan bakteri yang mempunyai kemampuan survive (bertahan hidup) yang sangat bagus terhadap fagositosis dari sel makrofag di dalam sel inang. Mtb memiliki kemampuan phenotypic switching yang berfungsi sebagai sistem mereplikasi ganda saat tubuh sel inang imunitas sistemnya turun, sehingga mempermudah bakteri Mtb untuk bereplikasi dan membunuh sel inang akibat infeksi bakteri tersebut (Parasa et al., 2014). Bakteri Mtb dalam keadaan non-replikasi mempunyai kemampuan berevolusi dan bertahan di dalam host cell dalam bentuk dormancy (non aktif) yang teriolasi di dalam granuloma (infeksi Tb laten) dalam waktu tertentu (Pai et al., 2016). Hanya Tb paru aktif yang dapat menular dan menyebabkan penyakit. Penyakit Tb terus menjadi masalah dunia mulai dari negara maju sampai berkembang.

Tuberkulosis (TB) tetap menjadi salah satu penyakit menular paling mematikan di dunia dan dianggap sebagai masalah kesehatan global utama, diperkirakan 8,6 juta orang penderita TB, dan 1,3 juta meninggal. Diperkirakan 9,0 juta penderita TB, dan 1,5 juta meninggal karena penyakit tersebut, 360.000 di antaranya adalah human immunodefciency virus (HIV) -positif. Di seluruh dunia, 9,6 juta orang diperkirakan jatuh sakitakibat TB sebanyak 5,4 juta laki-laki, 3,2 juta perempuan, dan 1,0 juta anak. Secara global, 12\% dari 9,6 juta kasus TB baru akibat HIV-positif. Mengingat kebanyakan kematian akibat TB dapat dicegah, angka kematian akibat penyakit ini sangat tinggi (Suzuki, 2019). Tingkat perkembangan penyakit Tb aktif sangat tinggi pada bayi yang terpajan, tapi jauh lebih rendah pada anak usia 2-10 tahun; resiko meningkat selama masa remaja dan usia produktif sekitar usia 25 tahun. Sedangkan Kejadian penyakit Tb aktif sekitar dua kali lipat lebih tinggi pada pria daripada wanita, dan sekitar 10\% dari semua kasus baru di seluruh dunia terjadi pada anak-anak (Faizal et al., 2018).

Penelitian kita yang membedakan dengan yang lain dan recent yaitu masih belum ada pengamatan pembentukan granuloma Tb secara in vitro pada tahap laten. Ketika patogen menginfeksi paru-paru, baik faktor bakteri dan menginduksi remodeling jaringan sel inang (host), maka menciptakan lesi inflamasi kronik yang dikenal sebagai granuloma. Struktur-struktur pembentukan granuloma ini berhubungan dengan pengendalian dan perkembangan penyakit (Marakalala et al. 2016). Kebanyakan penelitian Tb lebih tertarik pada Tb pada tahap kronis setelah bakteri menginfeksi sehingga kedepannya penelitian ini sebagai langkap awal diagnosa pengobatan, diagnosa pada aspek dan peran sel imunologi sehingga kedepan sebagai pengembangan vaksin baru pada early phase untuk mengimplementasikan program dan pembiayaan yang lebih baik diperlukan untuk mengakhiri epidemi Tb global pada tahun 2035. 


\section{Metode Penelitian}

Jenis penelitian ini adalah eksperimen murni dengan metode in vitro pembuatan model TB granuloma yang mirip dengan manusia. Penelitian ini menggunakan isolat bakteri Mycobacterium tuberculosis H37Rv yang diperoleh dari Laboratorium Mikrobiologi Institut Penyakit Tropis Universitas Airlangga, Surabaya. Kemudian membuat model granuloma menggunakan media Peripheral Blood Mononuclear Cells (PBMC). Pembuatan media PBMC menggunakan sel darah sebanyak 10 cc kemudian disentifugasi pada $2000 \mathrm{rpm}$ selama 10 menit, kemudian plasma darah dipindahkan ke tabung $1,5 \mathrm{ml}$ (simpan pada suhu $-80^{\circ} \mathrm{C}$ ). Sebanyak $3 \mathrm{ml}$ Phospahte Buffer Saline (PBS) ditambahkan ke dalam tabung conikel yang berisi sampel. Kemudian menambahkan sebanyak $5 \mathrm{ml}$ histopague ke tabung conikel (dilakukan pengulangan sebanyak 3x dengan prosedur yang sama, dan tiap pengulangan diganti dengan conikel baru). Saat pengulangan ke-4 maka dipindahkan ke conikel yang baru lalu sentrifugasi pada $1700 \mathrm{rpm}$ selama 30 menit. Setelah itu dibuang cairan atas (plasma) dan pindahkan cairan tengah (buffy coat) ke dalam tabung conikel baru. PBS ditambahkan $1 \mathrm{x}$ hingga $15 \mathrm{ml}$ ke dalam tabung conikel yang mengandung cairan tengah (buffy coat) dan kemudian disentrifugasi selama 5 menit pada $1500 \mathrm{rpm}$. Kemudian cairan atas (plasma) dikeluarkan dan ditambahkan PBS 1x ke 15 ml kemudian disentrifugasi $1.300 \mathrm{rpm}$ selama 5 menit. Kemudian cairan dikeluarkan dan ditambahkan $600 \mu$ PBS 1x dan dicampur menggunakan mikro pipet. Kemudian pindahkan ke tabung 1,5 ml dan simpan pada suhu $-30^{\circ} \mathrm{C}$.

Setelah itu media PBMC yang telah dikultur ditambahkan dengan Roswell Park Memorial Institute (RPMI) dan kemudian isolat bakteri strain Mycobacterium tuberculosis $H 37 R v$ diinokulasi sebanyak 1x 10 CFU (hari ke-1) ke dalam 1 well. Setelah itu, diambil sebanyak $10 \mu \mathrm{l}$ untuk dipanen dan ditempatkan di objek gelas polielisin dan diamati di bawah mikroskop untuk mengamati bentuk morfologi granuloma TB (pada pengamatan hari ke-1), dan tahap selanjutnya diamati pada hari ke-2, hari ke-3, hari ke-4 dan hari ke-5 dengan prosedur yang sama.

\section{Hasil Penelitian dan Pembahasan}

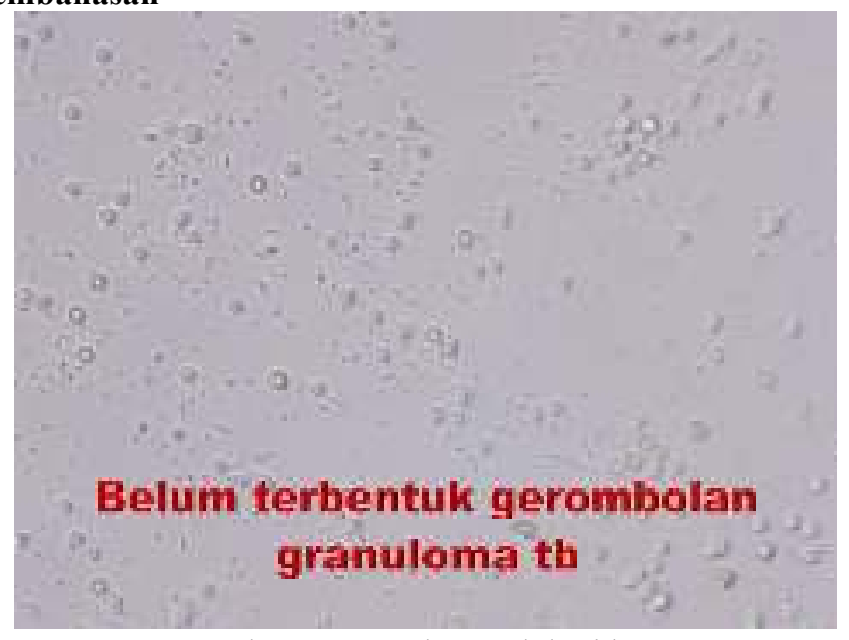

Gambar 1. Granuloma Tb hari ke-1 
Jurnal Analis Medika Biosains (JAMBS)

Vol.7, No.2, September 2020, pp. 140 - 145

ISSN: 2656-2456 (Online)

ISSN: 2356-4075 (Print)

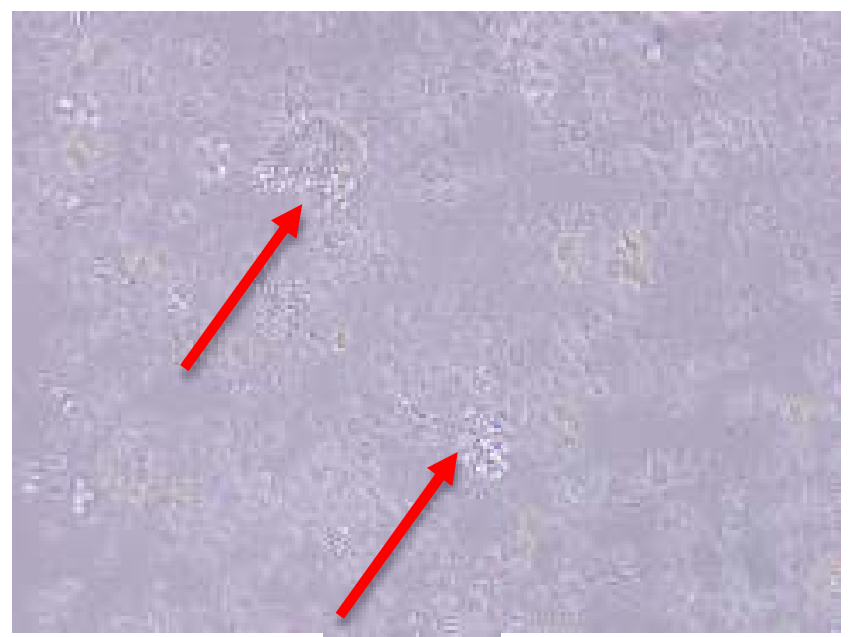

Gambar 2. Granuloma Tb hari ke-2

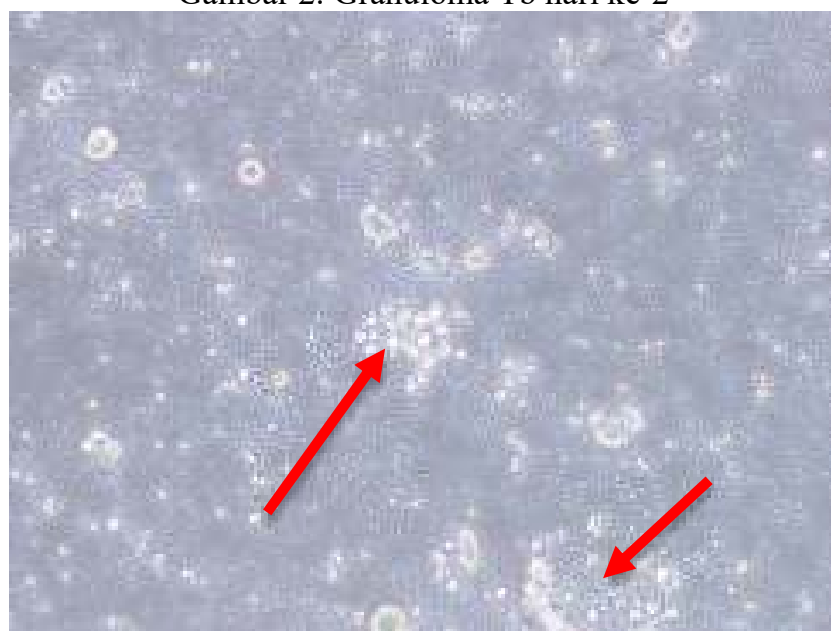

Gambar 3. Granuloma Tb hari ke-3

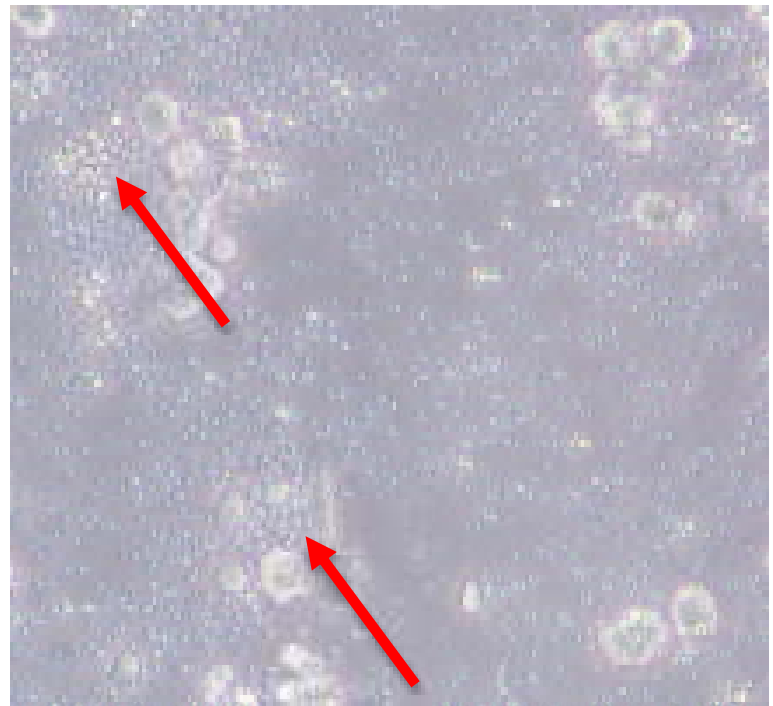

Gambar 4. Granuloma Tb hari ke-4. 


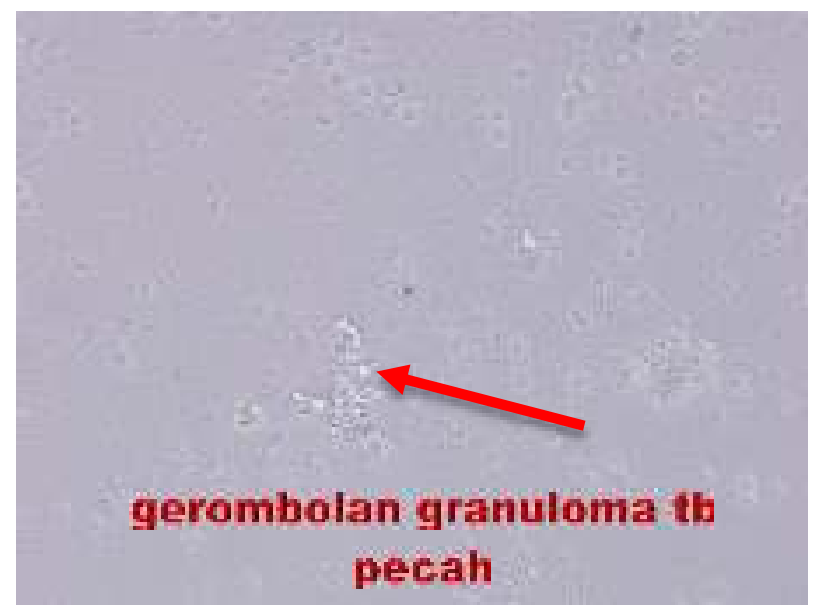

Gambar 5. Granuloma Tb hari ke-5

Hasil penelitian bahwasanya pada hari ke-1 granuloma belum terbentuk dikarenakan pada gambar 1 struktur granuloma belum terbentuk terjadi karena sel imun darah pada media PBMC berisi sel limfosit dan monosit merupakan belum merespon terhadap infeksi Mtb (Panda \& Ravindran, 2013). Granuloma adalah ciri khas infeksi Mycobacterium tuberculosis dan secara imunopatogenesis Tb pada tahap early phase pada penderita terinfeksi secara laten. Struktur granuloma berbentuk bergerombol, terorganisir agregat sel kekebalan yang terdiri dari berbagai sel imun innate maupun sel imun adaptive diantaranya sel makrofag, foamy macrophage (turunan dari sel makrofag yang berproliferasi karena respon adanya infeksi bakteri M.tb) (Genoula et al., 2018) sel epitel, sel raksasa multinukleat (sel Langerhans) dikelilingi oleh cincin limfosit (Guirado \& Schlesinger, 2013). Pada hari ke-2 struktur granuloma mengelilingi bakteri Mtb sudah memulai terbentuk membentuk agregrasi yang dominan yaitu sel makrofag yang bisa dilihat pada gambar ke-2. Banyak jenis sel lainnya komposisi membentuk granuloma, seperti neutrofil, sel dendritik, Sel B dan T, natural killer cells, fibroblas dan sel yang mengeluarkan komponen matriks ekstraselular yang pada akhirnya membentuk formasi granuloma tb yang melindungi organ paru agar bakteri Mtb tidak bisa reaktifasi (Ramakrishnan, 2012). pada gambar ke-3.

Puncak pembentukan granuloma yang sempurna terjadi pada hari ke-4 dapat dilihat pada gambar gambar 4. Setelah hari ke-4 granuloma mengalami granulasi (pecah). Fungsi utama granuloma adalah lokalisasi dan menahan Mtb dan memusatkan proteksi respon imun terhadap area terbatas yang terinfeksi Tb (Peddireddy et al., 2017). Dilihat pada gambar 5 struktur granuloma pecah dan agregrasi rusak maksimal terjadi pada hari ke-5. Jika sel host imunitasnya kuat maka granuloma akan tetap melindungi dari infeksi Mtb jika melemah maka Mtb akan bisa menembus perlindungan granuloma.

Sedangkan ketika sistem kekebalan inang melemah, diketahui bahwasanya granuloma tb bisa menjadi indikator tingkat keparahan penderita tuberkulosis dan mencegah terjadinya bakteri mtb re-aktivasi. Bukti eksperimental telah mengungkapkan bahwa faktor TNF- $\alpha$ memainkan peran utama dalam pertahanan inang melawan Mtb baik pada fase infeksi aktif maupun kronis. Data menunjukkan bahwa beberapa aktivitas TNF$\alpha$ diperlukan untuk menjaga integritas granuloma dan untuk membatasi patogen Tb (Birkness et al., 2007). 


\section{Kesimpulan}

Penelitian dapat disimpulkan bahwasanya tingkat keparahan penderita tuberkulosis dapat dideteksi sejak dini dengan metode pengamatan in vitro granuloma dengan melihat morfologi terbentuknya granuloma tb sehingga agar memberikan terapi obat yang tepat, bahkan penelitian ini bisa digunakan sebagai tahap awal penyempurnaan vaksin pada infeksi bakteri Mycobacterium tuberculosis.

\section{Daftar Pustaka}

Birkness, K. A., Guarner, J., Sable, S. B., Tripp, R. A., Kellar, K. L., Bartlett, J., \& Quinn, F. D. (2007). An in vitro model of the leukocyte interactions associated with granuloma formation in Mycobacterium tuberculosis infection. April 2006, 160-168. https://doi.org/10.1038/sj.icb.7100019

Faizal, I. A., Dwi, A., Widodo, W., \& Nugraha, J. (2018). The Effect of Macrophage Dose to Secretion Interleukin 6 ( IL-6 ) on Model of Tuberculosis Granuloma In Vitro. Proceedings of the 2nd International Conference Postgraduate School (ICPS), 6, 306-311. https://doi.org/10.5220/0007541803060311

Fitzgerald, L. E., Abendaño, N., Juste, R. A., \& Alonso-hearn, M. (2014). Three-Dimensional In Vitro Models of Granuloma to and Resuscitation of Dormant Mycobacteria. 2014.

Genoula, M., Franco, J. L. M., Dupont, M., Kviatcovsky, D., Milillo, A., Schierloh, P., Moraña, E. J., Poggi, S., Palmero, D., Mata-Espinosa, D., González-Domínguez, E., Contreras, J. C. L., Barrionuevo, P., Rearte, B., Moreno, M. O. C., Fontanals, A., Asis, A. C., Gago, G., Cougoule, C., .. Balboa, L. (2018). Formation of foamy macrophages by tuberculous pleural effusions is triggered by the interleukin10/signal transducer and activator of transcription 3 axis through ACAT upregulation. Frontiers in Immunology, 9(MAR). https://doi.org/10.3389/fimmu.2018.00459

Guirado, E., \& Schlesinger, L. S. (2013). Modeling the Mycobacterium tuberculosis granuloma - the critical battlefield in host immunity and disease. Frontiers in Immunology, 4(April), 1-7. https://doi.org/10.3389/fimmu.2013.00098

Mezouar, S., Diarra, I., Roudier, J., Desnues, B., \& Mege, J. L. (2019). Tumor necrosis factor-alpha antagonist interferes with the formation of granulomatous multinucleated giant cells: New insights into Mycobacterium tuberculosis infection. Frontiers in Immunology, 10(AUG). https://doi.org/10.3389/fimmu.2019.01947

Pai, M., Behr, M. A., Dowdy, D., Dheda, K., Divangahi, M., Boehme, C. C., Ginsberg, A., Swaminathan, S., Spigelman, M., Getahun, H., Menzies, D., \& Raviglione, M. (2016). Tuberculosis. Nature Reviews Disease Primers, 2, 16076. https://doi.org/10.1038/nrdp.2016.76

Panda, S. K., \& Ravindran, B. (2013). In vitro Culture of Human PBMCs. 3, 6-8. http://www.bioprotocol.org/e322

Parasa, V. R., Rahman, M. J., Thu, A., Hoang, N., Brighenti, S., Lerm, M., Parasa, V. R., Rahman, M. J., Thu, A., Hoang, N., Brighenti, S., Lerm, M., Mycobacterium, M., Parasa, V. R., Rahman, M. J., Thu, A., Hoang, N., \& Svensson, M. (2014). Modeling Mycobacterium tuberculosis early granuloma formation in experimental human lung tissue. The Company of Biologist, 7, 281-288. https://doi.org/10.1242/dmm.013854

Peddireddy, V., Doddam, S. N., \& Ahmed, N. (2017). Mycobacterial dormancy systems and host responses in tuberculosis. Frontiers in Immunology, 8(FEB), 1-19. https://doi.org/10.3389/fimmu.2017.00084

Ramakrishnan, L. (2012). Revisiting the role of the granuloma in tuberculosis. Nature Reviews Immunology, 12(5), 352-366. https://doi.org/10.1038/nri3211

Suzuki, K. (2019). Extrapulmonary tuberculosis. In A. Sener \& H. Erdem (Eds.), Japanese Journal of Chest Diseases (Vol. 73, Issue 9). Springer Nature Switzerland. https://doi.org/https://doi.org/10.1007/978-3030-04744-3 